\title{
The limits to large-scale supply augmentation: exploring the crossroads of conflicting urban water system development pathways
}

\author{
Jonatan Godinez Madrigal $^{1,2}$, Nora Van Cauwenbergh ${ }^{1}$, Jaime Hoogesteger ${ }^{3}$, Pamela Claure Gutierrez ${ }^{1}$, and \\ Pieter van der Zaag $^{1,2}$ \\ ${ }^{1}$ Department of Land and Water Management, IHE Delft, Delft, the Netherlands \\ ${ }^{2}$ Water Management Department, TU Delft, Delft, the Netherlands \\ ${ }^{3}$ Water Resources Management Group, Wageningen University, Wageningen, the Netherlands
}

Correspondence: Jonatan Godinez Madrigal (j.godinezmadrigal@gmail.com)

Received: 13 August 2021 - Discussion started: 17 August 2021

Revised: 11 January 2022 - Accepted: 12 January 2022 - Published: 18 February 2022

\begin{abstract}
Managers of urban water systems constantly make decisions to guarantee water services by overcoming problems related to supply-demand imbalances. A preferred strategy has been supply augmentation through hydraulic infrastructure development. However, despite considerable investments, many systems seem to be trapped in lacklustre development pathways making some problems seem like an enduring, almost stubborn, characteristic of the systems: overexploitation and pollution of water sources, distribution networks overwhelmed by leakages and non-revenue water, and unequal water insecurity. Because of these strategies and persistent problems, water conflicts have emerged, whereby social actors oppose these strategies and propose alternative technologies and strategies. This can create development pathway crossroads of the urban water system, defined as a critical point whereby actors in conflict will either reinforce the current business-as-usual pathway based on large supply augmentation or implement alternative solutions for the urban water system. To study this development pathway crossroads, we selected the Zapotillo conflict in Mexico where a large supply augmentation project for two cities experiencing water shortages is at stake. The paper concludes that urban water systems that are engaged in a trajectory characterized by supply-side strategies may experience a temporal relief but neglect equally pressing issues that stymie the human right to water in the medium and long run. However, there is not a straightforward, self-evident development pathway to choose from, only a range of multiple alternatives with multi-
\end{abstract}

ple trade-offs that need to be thoroughly discussed and negotiated between the stakeholders. We argue that this development pathway crossroads can cross-fertilize contrasting disciplines such as socio-hydrology and critical studies on water because both can complement technical and socio-political analyses to make their knowledge actionable and relevant.

\section{Introduction}

Urban water systems, understood as the managerial, technological, and infrastructural configuration of water supply in a city interlinked with its diverse water resources, have become vulnerable in the face of climate change and uncontrolled urban growth (Flörke et al., 2018). This alarming situation poses a risk that may sever water security for billions of people (WWAP, 2019; UNESCO, UNWater, 2020). Historically, water managers have uncritically implemented large supply augmentation projects as their main strategy (Allan, 2003; Molle, 2008; McCulligh and Tetreault, 2017; Boelens et al., 2019), despite the increasing evidence of its shortfalls (Gupta and Van der Zaag, 2008; Gohari et al., 2013; Rinaudo and Barraqué, 2015; Purvis and Dinar, 2020). However, affected communities have initiated grassroots movements and shown a strong opposition against the implementation of these projects. In some cases, these movements have been effective in delaying or even cancelling these projects (Ahlers et al., 2017; Godinez-Madrigal et al., 2020). 
Hundreds of water conflicts have emerged in the past decades, many of which are related to the implementation of large water infrastructure development (EJOLT, 2021). The importance of these conflicts is that they have played a key role in redefining the decision space of cities and basins to address pressing problems like water shortages and poor water quality (Rodríguez-Labajos and Martínez-Alier, 2015; Ochoa-García and Rist, 2018). The decision space in such conflicts is characterized by competing approaches either based on business-as-usual pathways like large-scale infrastructure or transitioning to alternative pathways (Godinez Madrigal et al., 2018a, 2020). This has generated an impasse, whereby large infrastructure projects are stalled due to the conflict, but alternatives remain untested. We call this situation characterized by conflict and indecisiveness in troubled urban water systems a development pathway crossroads, in which the actors in conflict will either define a new pathway or reinforce the current one.

Overcoming this crossroads is of extreme importance since it will imprint long-lasting consequences for the water security and water justice expressed in institutional arrangements and infrastructural configurations of the urban water system in question. For instance, in business-as-usual scenarios based on large infrastructure, Kallis (2010) observed a recurring phenomenon in the co-evolution of cities and water systems, dubbed the "supply-demand cycle", in which additional sources of water supply fostered a societal response that increased water demand. Thus, a larger water demand warranted developing new sources of water supply, fuelling the cycle, externalizing social and environmental costs to rural populations (Kallis, 2010), and exacerbating uneven water access in urban and suburban populations (Savelli et al., 2021). Moreover, a high dependence on reservoirs may render cities more vulnerable to hydro-climatic variations (Kuil et al., 2016; Di Baldassarre et al., 2018). Therefore, if water conflicts and grassroots movements can redefine the decision space of urban water systems, they will also interfere with the socio-economic, political, and hydroclimatic dynamics that reproduce the supply-demand cycle.

To understand the origins, extent, and possible consequences of this development pathway crossroads, it is necessary to study both the interdependent relationship between the coupled human and water systems and the power dynamics that configure the decision space within the urban water system. To test and analyse the concept of development pathway crossroads, we draw on empirical work on the Mexican urban heartlands of León and Guadalajara suffering from water shortages and overexploited water resources and their water security strategy of increasing water supply through an intra-basin water transfer. This infrastructure project has caused a 15-year-old intractable water conflict between the cities and three villages within the projected reservoir's site who have fought not to be relocated. The villagers formed a grassroots movement that has been successful in stalling the implementation of the infrastructure project and lobbying for the implementation of alternative strategies in the two recipient urban water systems. In this paper, we aim to explore the concept of development pathway crossroads to visualize the role of water conflicts and grassroots movements as a heterogeneous social response in coupled human-water systems characterized by the supply-demand cycle. We first ask what hydrological, technical, and socio-economic and political factors are triggering the supply-demand cycle in León and Guadalajara. Then, we describe and analyse how grassroots movements can redefine the decision space of urban water systems to address water shortages and act as a feedback mechanism that could disrupt the supply-demand cycle of urban water systems.

The paper is organized as follows. First, we discuss the relevant literature to develop our concept of development pathway crossroads in urban water systems. Second, we describe the methodology, which involved ethnographic techniques and participatory modelling. Then, we present the results and finally discuss the relevance of the case to the understanding of development pathway crossroads.

\section{Development pathway crossroads in urban water systems}

With habitual news headlines of cities reaching tipping points and "day zeros" in urban water systems (Maxmen, 2018), academic articles and reports calculating in the future billions of people without access to water (Vörösmarty et al., 2010; Schlosser et al., 2014; Mekonnen and Hoekstra, 2016; WWAP, 2019), and the incorporation of water in the investments of commodities of futures due to the growing fears for its scarcity (Bloomberg, 2020), water managers keep implementing a limited number of tried and tested strategies based on large infrastructure that no longer respond to emerging drivers of change (Leach et al., 2010; Larsen et al., 2016). In contrast, water managers underestimate the potential of alternatives and trivialize negative social and environmental effects of large infrastructure (Global Water Partnership, 2012; Godinez Madrigal et al., 2020). This phenomenon is relevant because this decision-making pattern often triggers unintended consequences in urban water systems such as contributing to a more pronounced water scarcity in the future (Gohari et al., 2013; Kuil et al., 2016; Li et al., 2019).

With a systems approach, Kallis (2010) conceptualized this phenomenon as the supply-demand cycle, which describes locked-in urban systems engaged in a constant dynamic of supply augmentation strategies, followed by an increased water demand in different economic sectors that overshoots again water availability. Moreover, Di Baldassarre et al. (2018) further developed this concept by describing the "reservoir effect", in which urban water systems become more vulnerable by increasing their dependence on external water sources that can be affected by future droughts. 
This systems approach has been the foundation of sociohydrological scholarship, which has mostly intended to understand what is happening with coupled human-water systems and why, instead of focusing on what should be done (Sivapalan and Blöschl, 2015). As a result, socio-hydrology has advanced the understanding of the prevalence of this large supply augmentation strategy in terms of co-evolution of human and water systems, infrastructure path dependence, locked-in systems, and feedback mechanisms of coupled human-water systems (Kallis, 2010; Gohari et al., 2013; Di Baldassarre et al., 2018; Li et al., 2019). However, there is a paucity of literature that has focused on case studies where the status quo has changed, especially through the emergence of grassroots movements (Rodriguez-Labajos and MartinezAlier, 2015), and the emergence of water conflicts, a research topic that remains under-researched (Di Baldassarre et al., 2019).

Kallis (2010, p. 807) glimpsed the potential to break the supply-demand cycle through "environmental changes, social and technical experiments, social movements and coalitions and innovations". However, few studies have analysed cases of social movements and water conflicts that have exerted a crucial change to a water system by widening the decision space to implement alternatives and interfere with pernicious supply-demand cycles (i.e. Platt, 1995, is a good example). A challenge to analysing complex cases involving water systems and human agency is that it requires a sound interdisciplinary integration (Wesselink et al., 2017; Rusca and Di Baldassarre, 2019; Di Baldassarre et al., 2019). For instance, Savelli et al. (2021) addressed how the lack of understanding of power relations and heterogeneity in sociohydrology may lead to overlooking differentiated responses and distribution of risks for diverse social groups in the case of Cape Town during the Day Zero drought. Societal responses and agency in contexts of power asymmetry need to be unpacked to better capture the diverse feedback mechanisms of coupled human-water systems.

Meanwhile, critical studies developed the concept of the hydrosocial cycle (Swyngedouw, 1997, 2004, 2009; Boelens, 2014; Linton and Budds, 2014; Schmidt, 2014), which internalizes the interplay of water and social power as a dialectic inherent to the cycle (Linton and Budds, 2014). Specifically, this approach has investigated how different distributions of water, authority, and knowledge in each society (re)produce several forms of exclusion and asymmetrical risks in different groups of society (Zwarteveen et al., 2017). In the case of the recurring decision-making pattern of large infrastructure implementation, critical studies have mobilized diverse approaches to understand how sanctioned discourses align the practices of decision makers, political economy of water management favouring the interests of prominent economic and political actors, psychological biases in decision making, and power embedded in knowledge asymmetries (Allan, 2003; Lach et al., 2005; Molle, 2008; Molle et al., 2009; Budds, 2008; Flyvbjerg et al., 2003; Flyvbjerg, 2009, 2014;
Hommes et al., 2016, 2019; Hommes and Boelens, 2017; Boelens et al., 2019). However, few critical studies engage in interdisciplinary research, which limits their transformative potential (Rusca and Di Baldassarre, 2019).

This is an important gap that needs to be addressed because, as discussed by Castree et al. (2014), Zeitoun et al. (2020), and Rusca and Di Baldassarre (2019), scientists have a moral obligation to change (not only to interpret) the world. Moreover, Lave et al. (2014) consider it imperative that more scientists "combine critical attention to relations of social power with deep knowledge of a particular field of biophysical science or technology in the service of social and environmental transformation". Therefore, innovative frameworks and methods are needed to engage in socio-environmental transformation by addressing the interplay between a diversity of actors that frame differently how to address the many challenges facing urban water systems and hydrological flows. Leach et al. (2010) offers a promising approach based on the concept of development pathways, understood as "particular directions in which interacting social, technological, and environmental systems co-evolve over time". Key elements of this approach are acknowledging the power dynamics and feedback mechanisms behind a current development pathway of a coupled naturehuman system and unearthing marginalized alternative narratives. This is critical since it highlights the possibility of change by emphasizing a need to widen the decision space to include these marginalized alternatives into negotiation and decision-making processes. A key question is to find which tools are appropriate to support unearthing and supporting alternative narratives that can compete with dominant development pathways.

\section{Methodology}

Considering the two research questions driving this paper regarding the multiple factors behind the supply-demand cycle in León and Guadalajara and investigating the role of water conflicts and grassroots movement in interfering with this cycle by showcasing alternative pathways, we conducted an inter- and transdisciplinary study. First, we employed sociohydrological and political ecology perspectives to analyse the long-term interplay of qualitative and quantitative factors that steer the co-evolution of the urban water systems of León and Guadalajara. We took inspiration from similar works that accounted for the political and socio-technical history behind these developments, such as Kallis (2008) on the co-evolution of water resources development in Athens, Molle and Wester (2009) on the longitudinal in-depth historic analysis of specific basins known as "river basin trajectories", Hommes and Boelens (2017) on the role of imaginaries of modernity and progress in justifying rural-urban water transfers, and Savelli et al. (2021) on the interplay of society and hydrological flows of Cape Town. In the context of 
the Zapotillo conflict, we conducted 29 semi-structured interviews with key stakeholders and decision makers of León and Guadalajara between 2017 and 2020. During that time, we also conducted participant observation in meetings, forums, and other workshops to which the first author was invited until the end of 2021. We chronicled those meetings in field notes which were commonly shared with the authors. We complemented these perspectives with official statistical data of both cities and requested unpublished information from both water utilities to understand the co-evolution of their infrastructural configuration and sociopolitical dynamics.

Second, as a method to showcase marginalized alternative narratives and their role in exerting a development pathway crossroads, we tested participatory modelling during a stakeholder workshop with the most important actors in the conflict in Jalisco during December 2018. Several studies have analysed the role of participatory modelling as an empowering design (Stirling et al., 2007) in contributing not only to our understanding of coupled human-water systems, but also the benefit of social processes like conflict resolution (Basco-Carrera et al., 2017, 2018; Van Cauwenbergh et al., 2018). Nevertheless, participatory modelling remains largely unexplored by socio-hydrology and hydrosocial studies to account for diverse social values in water systems and unveil power and knowledge asymmetries between actors (Melsen et al., 2018; Srinivasan et al., 2018). To the best of our knowledge, in the context of supply-demand cycle and the emergence of water conflicts and grassroots movements, this tool has not been used yet. We invited representatives in favour of the supply augmentation project of El Zapotillo - Conagua (National Water Commission), IMTA (Mexican Institute of Water Technology, the technical branch of Conagua), Jalisco's government, the college of civil engineers, actors of the grassroots movement - community members of Temacapulín and affected communities downstream, IMDEC (Mexican Institute of Community Development, a prominent NGO working with the dam-affected communities of Temacapulín, Acasico, and Palmarejo), Tómala (a civil society group involved in facilitating dialogue around important societal challenges in Jalisco), and academics of local universities. The Supplement of this paper describes in detail the variables and development of the model, which we dubbed SimVerde (Craven, 2018; Godinez Madrigal et al., 2018b).

\section{Results}

\subsection{The co-evolution of the urban water systems of León and Guadalajara}

With a population of approximately 1.5 million in the city of León and 4.5 million in Guadalajara, these are the two most important cities of western Mexico (Fig. 1). Due to the water shortages and groundwater overexploitation experienced in both cities, Conagua developed the intra-basin water transfer Zapotillo project, a large supply augmentation infrastructure to increase urban water supply. The subsections below describe the urban water system development pathways of León and Guadalajara to understand how certain hydrological, technical, socio-economic, and political factors explain the development of this infrastructural solution.

\subsubsection{León}

Currently, León's water system appears to be in a dire situation. Local and national authorities recognize a severe overexploitation of groundwater averaging a decline rate of $1.5 \mathrm{~m} \mathrm{yr}^{-1}$ (SAPAL, 2015). This level of overexploitation has had increasing negative consequences for the water quality of its aquifer (Villalobos-Aragón et al., 2012; Cortés et al., 2015). Despite this, León is the most economically vibrant city of Guanajuato, producing $25 \%$ of its GDP, partly due to its vibrant leather industry (Herrera, 2017, p. 86), and it has the largest population, which grows at a rate of $2 \%$ per year (Fig. 2). This constitutes a water challenge (or a dilemma) since this level of growth and groundwater overexploitation seems untenable in the long term.

The history of León's water utility can be divided into two periods: one, where the local government ran the water utility until 1988, and a second one, where the water utility became autonomous under the rule of an administration committee formed by representatives of various sectors of society, especially business people. In the first period, pork-barrel politics characterized the water utility's administration, a common practice during the authoritative regime of PRI (Partido Revolucionario Institucional) (Costa-i-Font et al., 2003). Keeping a low-cost, albeit crumbling, water service was important for the political aspirations for the city mayors. Non-revenue water reached $60 \%$, neglected infrastructure caused high levels of physical losses, and poor bookkeeping and corruption led to high commercial losses (Herrera, 2017). As a result, only $37 \%$ of users enjoyed daily water service, while poor neighbourhoods would suffer no water service for days (Herrera, 2017).

The second period started during the late 1980s, when, under the influence of international organizations like the World Bank and the IMF, Mexico began adopting neoliberal privatization policies as a remedy to the overall perception of the state inefficiency. In 1988, under the notion that water shortages were limiting their growth, several business organizations in León coalesced under the banner of democratizing the municipality of León and improving its water service by giving autonomy to the water utility. During the 1988 local elections, this coalition ran under PAN (Partido Acción Nacional), a pro-business political party, and won the election.

In the 1990s, the city sought to invigorate its vibrant leather industry and, with the new free-trade agreement with the United States and Canada, to attract foreign investment. 


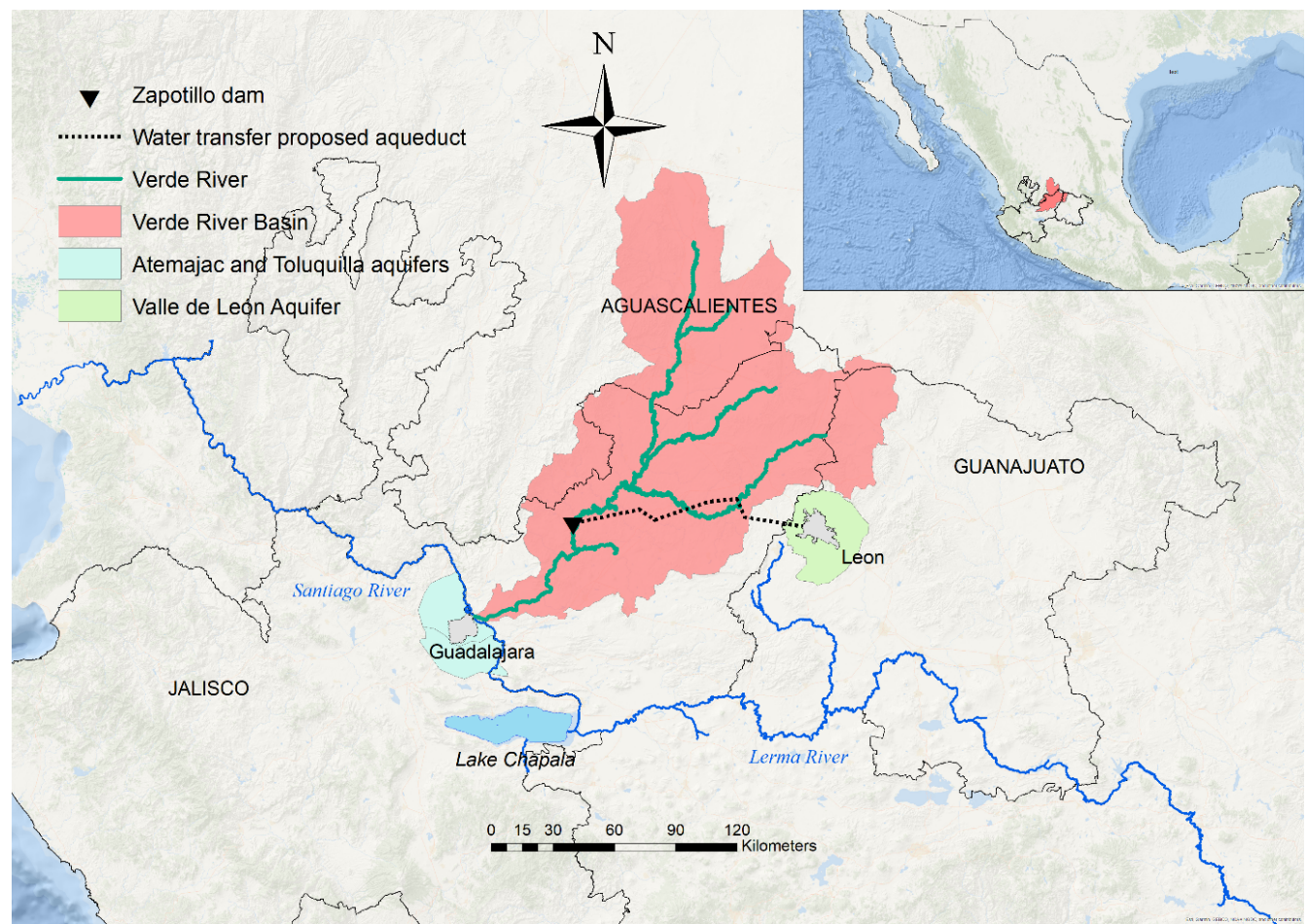

Figure 1. Map of the Verde River basin and main cities (source of GIS layers: (C) Conagua , 2018, and () Esri , 2019, Garmin, GEBCO, NOAA NGDC, and other contributors).

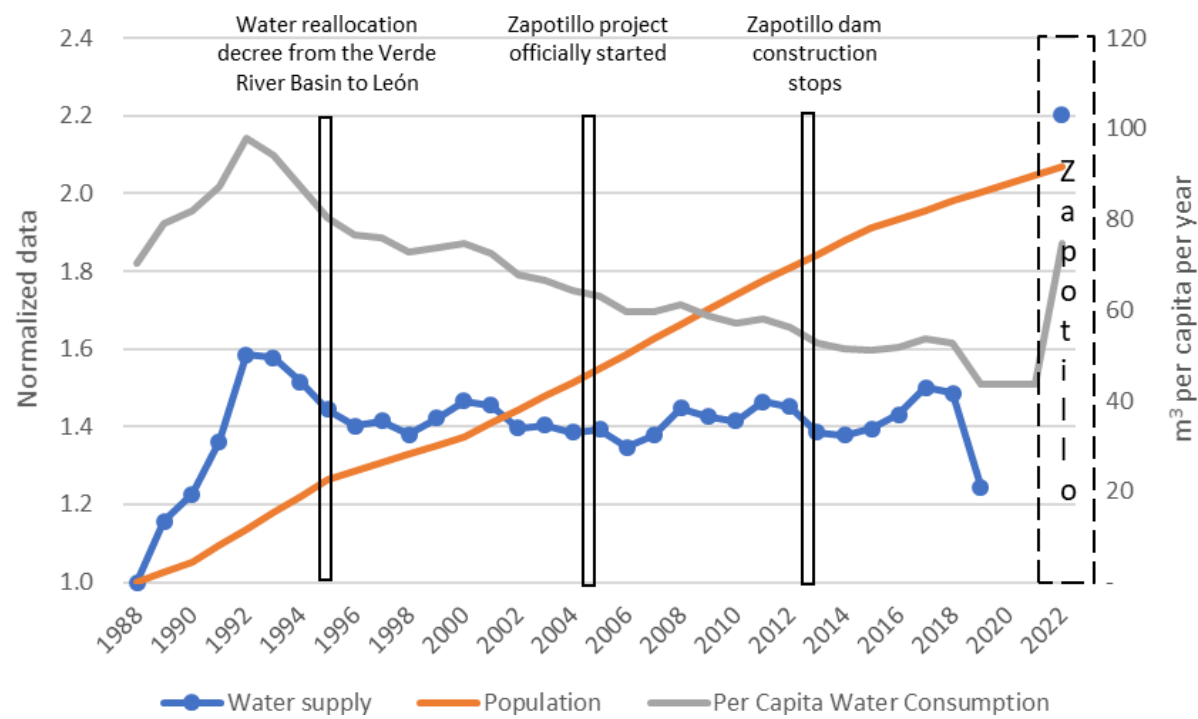

Figure 2. The reservoir effect in León (the dashed rectangle denotes the projected new water demand of a large new supply-augmentation scheme). Sources of data: INEGI (1990, 1995, 2000, 2005, 2010, 2015), CONAPO (2015), CEA Guanajuato and Conagua (2018), and SAPAL (2020).

This also marked a political transition to favour industrialization and export agro-export businesses as a vehicle to development, leaving traditional farming as a thing of the past (Godinez Madrigal et al., 2019). However, politicians and business organizations recognized that limited water avail- ability in the region and severe groundwater overexploitation represented a limiting factor for a sustained economic development of León and Guanajuato (Rodriguez, 2004, 2008; Herrera, 2017; Pastrana et al., 2017). 
To solve this problem, the business-led water utility aimed at running the water utility as a business and relied on two strategies to improve the water service of León: one, depoliticizing the prices of the water service to increase physical and commercial efficiency beyond cost recovery (Tagle-Zamora and Caldera-Ortega, 2021), and two, since the 1990s, lobbying for a large water transfer (Godinez Madrigal et al., 2020). These two strategies were interlinked, since with the financial surplus of the utility's efficiency, the water utility could partially afford the high costs of the water transfer.

The first strategy made León's water tariffs the highest in the country, and, consequently, per capita water use became one of the lowest in the country (Consejo Consultivo del Agua, 2011). This strategy was so effective in improving the utility's efficiency (reducing non-revenue water from more than $60 \%$ to less than $35 \%$ and water coverage improving to almost $95 \%$ ) that Conagua awarded them with the prize for the best managed utility in the country in 2012 . However, the public perception of the utility's price hikes was that the utility operated as a business instead of a steward of the human right to water (Caldera-Ortega, 2009, 2014; Lozano, 2014). Domestic water users experienced a sudden hike in their costs, with the poorest users struggling to pay the water bills, while large automotive industries were attracted with water access subsidies (García Garnica and Martínez-Martínez, 2018; García-Garnica, 2017). This strategy has also brought about unintentional consequences, since it led many industries, especially the small units of the leather industry, to resort to the black market, where they would buy water tankers from farmers engulfed by the city sprawl (Caldera-Ortega and Tagle Zamora, 2017; Hernández-González, 2020). This also indicates that SAPAL's (León's water utility) official water demand might be underestimated. Despite this, the policies of the city and the state have incentivized the formation of long-term large industrial clusters in the region by promising secured water supply (García-Garnica, 2017).

With the second strategy (the Zapotillo project), León and Guanajuato's authorities sought a water reallocation from the nearest sub-basin, the Verde River basin, which Conagua awarded in 1995. However, the materialization of an infrastructure project was delayed until 2005, when the then Mexican president (Vicente Fox, a former governor of Guanajuato) and the governors of Jalisco and Guanajuato belonged to the same political party of PAN. The importance conferred to this project was such that SAPAL's director mentioned that

[I]f we do not undertake a [supply augmentation] project in the coming five years [...], we will not be able to have the same growth in León as we have today. We need to bring water, because we can still grow for five more years; afterwards, although we can sustain the supply to the city, we would need to halt its growth. (Rodríguez, 2004)

However, since 2013 the project and dam construction have been stopped because of a social conflict of the dam- affected communities (Godinez-Madrigal et al., 2020). In response to the growing water demand of the rapidly growing city, SAPAL expanded its groundwater supply network to the aquifer of León as well as in the neighbouring aquifers of Silao-Romita, Turbio River, and La Muralla. The number of deep tube wells of SAPAL grew from 124 in 2008 to 196 in 2019 and is pumping at ever increasing depths in all aquifers (Konijnenberg, 2019), in a context in which groundwater use for agriculture (accounting for up to $80 \%$ of all extracted groundwater, from more than 18000 wells) has gone by and large unchecked because of toothless demand management institutions and weak and incomplete administration and regulatory systems (Hoogesteger and Wester, 2017).

Although it is still unclear whether the project can be finalized, SAPAL and Guanajuato's government consider the Zapotillo project not only the preferred but the only solution to bring water security to León (SAPAL, 2009, 2012, 2016; CEA Guanajuato and Conagua, 2018). However, it is still uncertain if the objective of the Zapotillo project is to contribute to the sustainability of the water system or to a sustained capitalist expansion since Guanajuato's water authority expects water demand to almost double when the Zapotillo project is implemented (see Fig. 2's dashed rectangle). Thus, even with the new water transfer, the authorities do not expect a reduction of the groundwater overexploitation, since the $3.8 \mathrm{~m}^{3} \mathrm{~s}^{-1}$ water transfer will not completely satisfy the new expected water demand of around $5 \mathrm{~m}^{3} \mathrm{~s}^{-1}$ (CEA Guanajuato and Conagua, 2018). This provides evidence of a future supply-demand cycle triggered by the Zapotillo project that will not reduce groundwater overexploitation because of an increased water demand.

In conclusion, although León has implemented promising strategies regarding cost-recovery and reclaimed wastewater, they have been limited in scale, partly due to the high expectations of the Zapotillo project to provide water security once and for all (Caldera-Ortega et al., 2020), which is a problematic expectation in light of the demand-supply cycle. Furthermore, León's and Guanajuato's authorities have passively accepted groundwater overexploitation by focusing on the Zapotillo project and overlooked an increased accumulation of groundwater rights in the hands of few powerful farmers, agro-export businesses, and industries that perpetuates a severely unsustainable groundwater dynamic (Hoogesteger and Wester, 2015; Hoogesteger, 2018).

\subsubsection{Guadalajara}

At the moment of writing this paper (2021), Guadalajara is suffering from a water shortage. The Calderón dam, a key water source contributing $14 \%$ of total water demand, is running dry, and Jalisco's politicians demand the continuation of the Zapotillo project as the only solution (Del Castillo, 2021). This is the latest event of a controversial issue that has characterized Guadalajara for the past decades: expanding its water sources to further regions to keep up with the apparent 
ever-increasing water demand (López-Ramírez and OchoaGarcía, 2012). The urban dynamics of Guadalajara have been characterized by a relentless urban growth that outpaces the capacity of the local governments to regulate it and the water utility to incorporate new urban stretches into the networked system (Castillo-Girón et al., 1994; Del Castillo, 2018; Gleason and Casiano, 2021). Consequently, the urban water system of Guadalajara resembles an infrastructure archipelago (Bakker, 2003; Allen et al., 2017), with approximately a hundred non-networked neighbourhoods with scarce water access (Greene, 2021), hundreds of networked but intermittent neighbourhoods with low water quality (Pérez-Peña et al., 2009; Rubino et al., 2019), and high-income neighbourhoods and large industries with an independent and secure groundwater source (González-Valencia, 2020). As a result, the city faces precarious and low-quality water access for hundreds of thousands of people and overexploited aquifers (PérezPeña et al., 2009; Rubino et al., 2019; Greene, 2021).

Historically, Guadalajara has benefited from three large supply augmentation projects in the past (Fig. 3). The first was based on groundwater supply augmentation in the late 1940s that has continuously expanded until today. However, the accelerated population growth (higher than $6 \%$ per year), typical of Latin American cities of the time (Camisa, 1972), and a severe drought created an image of acute water scarcity. This generated a pressure to increase water supply sources. Therefore, in 1956 when the drought ended, Guadalajara's government decided to build the Atequiza sluice to make use of the largest natural lake in Mexico, Lake Chapala. The city also built a large drinking-water plant with an installed capacity of $9 \mathrm{~m}^{3} \mathrm{~s}^{-1}$ (more than 2-fold what was needed) to increase water supply from the lake on demand. The governor of Jalisco considered this project "monumental" and a permanent solution to water scarcity for Guadalajara (PérezPeña and Torres-González, 2001). Moreover, the project was embedded in a larger policy of the hydraulic mission to make water available as much as possible for economic and urban uses (Boehm Schoendube, 2005), a tendency that later led to basin closure and water conflicts between Jalisco and Guanajuato (Wester et al., 2005; Godinez-Madrigal et al., 2019).

However, the "permanent" Lake Chapala solution lasted only a couple of decades because during the 1970s and 1980s, Guadalajara's increased water demand did overshoot water availability again. Therefore, the local authorities created SIAPA (Sistema Intermunicipal de Agua Potable y Alcantarillado) in 1978, an intermunicipal water utility to increase the water management capacity of the growing city. However, expert engineering and management knowledge have always been secondary to varied vested interests of Jalisco's government (Del Castillo, 2018). Therefore, the water managers and engineers needed to solve water problems without affecting the status quo of a continuous expanding city and a large per capita water consumption $(\approx 300 \mathrm{~L}$ per capita per day). Next, water engineers of Jalisco and Conagua developed a basin development plan of the Verde River basin, known as Zurda-Calderón, to build more than 15 dams to expand Guadalajara's water supply to meet an estimated future water demand of Guadalajara of $24 \mathrm{~m}^{3} \mathrm{~s}^{-1}$ by the year 2000, more than double the city's actual water use in 2021 (FloresBerrones, 1987; Cabrales-Barajas et al., 1993; Ochoa-García et al., 2014). To date, only Calderón dam $\left(1.5 \mathrm{~m}^{3} \mathrm{~s}^{-1}\right)$ has been implemented.

Although integrating urban planning with water management would have contributed to alleviate the increasing pressure over Guadalajara's water supply sources, the city's dynamics (as in many other cities in Mexico) has been characterized by a deregulated urban planning and an unrestrained urban speculation fostered by national neoliberal policies (Pérez-Peña et al., 2009; Pfannenstein et al., 2017; Reis, 2017; Greene, 2021). "Guadalajara's business model is to expand horizontally and vertically" (Del Castillo, 2018). As a result, SIAPA was perceived as a water utility mainly managed to generate political and economic gains rather than a good service based on technical and administrative sound decisions (Del Castillo, 2011).

In the last 30 years, the network system deteriorated to a point where water service became intermittent and poor water quality led to the bottled water industry completely replacing tap water for human consumption (UASLP and CEA Jalisco, 2010; Greene, 2018, 2021; McCulligh et al., 2020). Under the neoliberal sanctioned discourse, this does not represent a problem since the market provided a solution to an inefficient public water utility. With this perspective, affluent neighbourhoods and large industries were also allowed to develop in protected natural areas and managed their own (secure) groundwater supply systems (Pérez-Peña et al., 2009; González-Valencia, 2020). Despite this, the focus has always been on the gap between demand and supply, with the recurring threat of water scarcity. This threat was especially tangible when in 2004 Lake Chapala suffered a water crisis again that threatened $70 \%$ of Guadalajara's water supply that depended on it (6 out of $9 \mathrm{~m}^{3} \mathrm{~s}^{-1}$ of Guadalajara's water demand). SIAPA suspended water service in several parts of the city (Flores-Elizondo, 2016). Continuing with a techno-managerial solution approach to solve the crisis, in 2004 Jalisco spent millions of dollars in prospective studies on an intra-basin water transfer project from the Santiago River called Arcediano, which would supply as much as $10 \mathrm{~m}^{3} \mathrm{~s}^{-1}$ to Guadalajara. The government had such high hopes that this project would solve the increasing water demand of Guadalajara in years to come that Jalisco's government ordered SIAPA to grant any new domestic water request: "We can't stop the city from growing" mentioned a high-ranking civil servant (Del Castillo, 2018). Whereas the water transfer was not yet concretized, it had already increased water demand. Ultimately, the Arcediano project fell apart due to geological complications (López-Ramírez, 2012), prompting the search for a new supply augmentation project. In the meantime, the distribution network continued to deteriorate, and water losses persisted, despite having the 


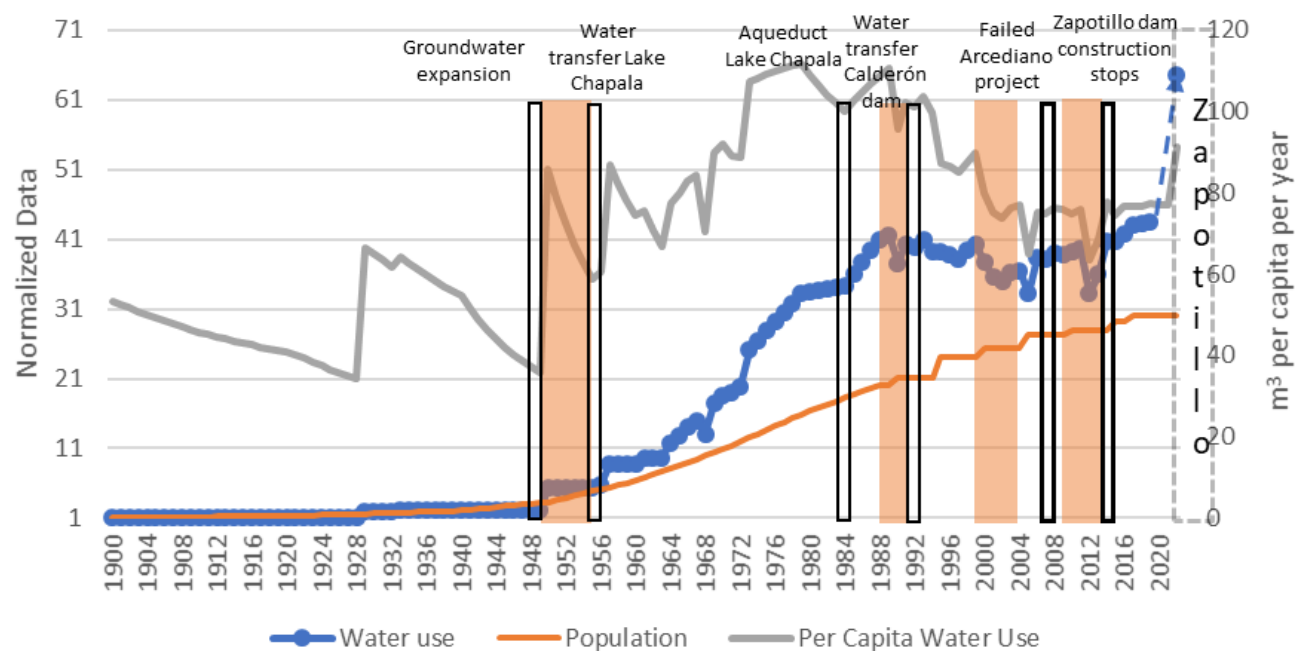

Figure 3. The reservoir effect in Guadalajara (the blue bars denote the implementation of a large supply augmentation schemes in 1947, 1956, and 1991, red bars the presence of droughts, and the dashed rectangle the official projected new water demand for the proposed large supply augmentation scheme). Sources of data: INEGI (1900, 1910, 1921, 1930, 1940, 1950, 1960, 1970, 1980, 1990, 1995, 2000, 2005, 2010, 2015), Duran Juárez and Torres Rodríguez (2001), Jalomo Aguirre (2011), Torres Rodríguez (2013), Conagua (2015), SIAPA (2014a, b, 2016, 2020), Gómez-Jauregui-Abdo (2015), and CEA Jalisco and Gobierno del Estado de Jalisco (2018).

technology to swiftly repair leaks (Delgado-Aguiñaga et al., 2017).

Currently, the entrenched faith in large supply augmentation infrastructure continues while pressing issues of highly unequal access to water of poor quality, overexploited groundwater, and unabated urban growth are neglected, as are the high levels of unaccounted for water of the water utility. This omission could rapidly offset the benefits of a large supply augmentation project because should the $\mathrm{Za}-$ potillo project be implemented, the state water authority expects water demand to grow to a level that would equalize the new water supply (represented by the dashed rectangle in Fig. 3; CEA Jalisco and Gobierno del Estado de Jalisco, 2018).

\subsection{Opening up the decision space}

The previous subsection shows that the growth of both cities has increased water demand beyond current water supply and for both cities the Zapotillo project is perceived not as the main but the only viable strategy to bridge that gap. However, both cities experience water problems beyond a gap between supply and demand that a large supply augmentation will not fix. On the contrary, there are indications in both cases that it could further foster a supply-demand cycle (Kallis, 2010) and possibly the reservoir effect by increasing their dependence on the Zapotillo reservoir (Di Baldassarre et al., 2018). Therefore, considering the conflict that has put the $\mathrm{Za}$ potillo project indefinitely on hold, the urban water systems of Guadalajara and León are facing a crossroads that warrants the question of what alternative solutions can address León's and Guadalajara's water problems and what their challenges, obstacles, and potential are.

The grassroots movement, consisting of the dam-affected communities, along with an international network of academics, practitioners and experts, has been developing and proposing a portfolio of alternative strategies with fewer socio-environmental externalities than the Zapotillo project (Godinez Madrigal et al., 2020). The main alternatives that have been debated in the media and the public agenda are rainwater harvesting, the limiting of urban growth, the reclaiming of wastewater reuse for industrial water demand, the implementation of water-saving devices, the reallocation of water from agro-export businesses to domestic uses, and the reduction of physical losses in the distribution system. However, local and state governments and water engineers conceived these alternatives as distractions to the only feasible solution, the Zapotillo project (anonymous interview with a retired water engineer of the state of Jalisco, 25 May 2018).

Many organizations say they have been fighting for 10,15 years for a position related to different alternative solutions for water [supply]. I think that if we continue like this for another 10, 15 years, then that method [sic] cannot deliver. It is just not possible to continue in the same situation for another 10 or 15 years. (transcript of a public talk of the head of the civil engineering college of Jalisco, 22 November 2018)

Even when the alternatives' potential is acknowledged, they are dismissed as unfeasible because "If we would consider implementing these projects [i.e. reducing physical losses and rainwater harvesting], it would take years and be 
very costly" (interview with the head of the Water Council of Jalisco, 22 December 2020). Nevertheless, these negative assessments of alternatives are not backed up by thorough studies but are based on a priori judgements on water knowledge and dubious expert opinions (interview with local academic, 8 December 2018).

However, these negative assessments have become a talking point for actors supporting the Zapotillo project. Water engineers have depicted the actors against the Zapotillo project as bad-faith opposers without a constructive criticism. In engineering circles, they are known as oposi-todos (anti-everything people) (anonymous interview with a retired water engineer of the state of Jalisco, 25 May 2018).

Conscious of how the governments and experts portrayed the grassroots movement, members of the movement introduced to the public discussion the need to look for alternatives to large-scale supply augmentation infrastructure besides their main argument that the Zapotillo project was a mistake. However, with limited expertise and scarce resources, the grassroots movement faced limitations to clearly argue which alternatives would be more suitable to Guadalajara and León and to what extent would they provide a reliable solution to the different needs of each city. Given this void, the authors of this paper collected the dispersed alternative solutions into an integrated water resources model (see Supplement).

These two contrasting narratives collided during our participatory modelling workshop to compare alternative water supply solutions and the Zapotillo project for Guadalajara and León. The workshop was powered by a water resources model originally used to assess the Zapotillo project using reliability, resilience, and vulnerability (Godinez Madrigal et al., 2020). We compiled the most important alternative solutions and built them into the model to assess and compare all alternatives. Through a user-friendly interface, participants could choose their preferred strategies and analyse their performance. However, this time the indicators were based on both perspectives against and in favour of the Zapotillo project: water supply reliability for León, Guadalajara, and water users in the donor basin, groundwater dynamics, and environmental flows.

During the workshop, engineering participants of IMTA opted to test the communities' position and the alternative solutions they proposed. Their overall criticism of the participatory model was the underlying assumptions of the alternatives and that models are much more complex than what lay people can understand.

To lay people it is very obscure what a model entails; it is not as easy as giving them a computer and off they go [...] [Regarding alternatives] you are trying to limit urban growth. I don't think that is viable, I didn't understand that [measure] of limiting urban growth [...] So, how are you going to make it happen [limit urban growth to $1 \% /$ year?]
It is unrealistic. If we are growing $2 \% /$ year, how am I going to decrease it to only 1 [\%/year], sure not magically.

Social actors comprised of NGOs and dam-affected communities preferred to test the performance of the Zapotillo project and realized that it would also take years before the dam could be filled and be ready to use for León and Guadalajara and that it would not be a solution for the groundwater overexploitation. As a response to the engineering group, they acknowledged that the data in the participatory model may not be optimal and found the need to democratically curate input data, which led them to critically assess how data and expert opinions of water managers and engineers could also easily be manipulated:

The model is not perfect, because there is incomplete information, and needs to have more adjustments to become more useful. But we agree that previous governmental models [that warranted the Zapotillo project] were also running with incomplete information and were biased by their own interests. [...] This tool can be useful for communities to criticize technical and political arguments and support alternatives because the situation can be analysed in a more integrated way, with more social criteria, not like the government's previous models. (representative of IMDEC)

Although all actors agreed that the model itself was incapable of finding an optimal solution to the conflict because of its inherent uncertainties and numerous configurations, most actors stated that participatory modelling could become a powerful process to engage actors to find negotiated solutions in the long run. They reflected on how essential it is to improve our governance processes to better deal with complex issues and uncertainties, since they cannot be reduced by technical studies, nor expert engineers:

The more connections we make [in the model], the less certainty we have, therefore, it is an issue of governance, where all actors must be present to discuss and build agreements, because there will never be a $100 \%$ satisfactory technical solution. (representative of Tómala)

Other civil society participants acknowledged the uncertainties of the model as well and considered that citizens should also be part of choosing which data to feed the model to increase trust. Especially for communities affected by socio-environmental problems, the modelling tool also seemed to have an additional potential:

I sincerely see this tool's potential not so much for helping make decisions, but for understanding what the problem is. I was envisioning... and felt emotional, that in my community we could 
have the chance to work the model with a lot of people. Because just imagine that the community could make a leap in understanding in a brief period of time a whole problem. (member of an affected community, 6 December 2018)

After the workshop, the head of Conagua and the engineers who participated in the workshop stated their commitment to continue developing alternatives to solve the conflict. This participatory modelling workshop led to follow-up activities. A year later some of the social actors who participated further explored alternative technical solutions by organizing a series of workshops in coordination with the newly elected leftist federal government of Mexico, in which three alternatives were further explored with the assistance of a dozen of international and national experts in different fields: improving groundwater management, including rainwater harvesting and reducing physical losses. However, the state governments of Jalisco and Guanajuato criticized and disapproved the participation and support of the federal government in these workshops on alternative solutions. The president of the business association of León mentioned that "We do not know the intention of these workshops, but we are against exploring new alternatives, especially if they are serious [...] All this affects our competitiveness." (Aristegui Noticias, 2019).

In this context, the public attention and federal public policies have shifted from the Zapotillo project as the only option, to the potential of alternative water solutions for Guadalajara and León. Currently (November 2021), the federal government has agreed to decrease the operation scale of the Zapotillo dam from $105 \mathrm{~m}$ to a maximum dam height of $50 \mathrm{~m}$ (which implies that the water supply from the dam to Guadalajara will reduce to $3 \mathrm{~m}^{3} \mathrm{~s}^{-1}$ and that the water transfer to León is cancelled) (Conagua, 2021) in order to spare the dam-affected communities. Guadalajara and León will either search for new, further, and more costly large-scale supply augmentation projects with the risk of triggering more conflicts or be forced to start experimenting and adopting some of the alternative solutions described in this paper.

\section{Discussion}

To fully understand the pathways of León and Guadalajara, they need to be framed under larger social, economic, and political dynamics and the Zapotillo supply augmentation project. With a sociohydrological perspective, we analysed the interplay of social and hydrological processes that resulted in the current predicament of León and Guadalajara. Moreover, our political ecology analysis of the co-evolution of Guadalajara's and León's human-water systems shows that although water managers have warranted the quest for new water supply sources based on the "inevitability" of socio-economic growth, we found that more than inevitable, socio-economic growth has been actively promoted as a development pathway.

Our results show that the Zapotillo project is conceived by the authorities' own accounts as a provisional strategy (CEA Guanajuato and Conagua, 2018; CEA Jalisco and Gobierno del Estado de Jalisco, 2018), since they would require additional future large supply augmentation infrastructure once water demand outstrips water supply again in the coming decades. This is so because there are socio-economic dynamics that are currently bounded by limited water availability, which would then be unleashed and be supported by an increased water supply. This behavioural pattern of cities and water managers is understood as a driver of the supplydemand cycle found in other cases around the world (Kallis, 2010; Di Baldassarre et al., 2018).

Analysing the case of Guadalajara through the lens of socio-hydrology, we found that the city's current water shortage and its concomitant socio-economic damage (as of June 2021) is the result of the increased water demand fostered by its intra-basin water transfers (Calderón dam and Lake Chapala) and its increased dependency on these reservoirs. Moreover, a critical perspective on this urban water system shows that the emphasis given to the large supplyaugmentation Zapotillo project will not fix the current situation of non-networked residents and the multiple network deficiencies (high physical losses and ageing infrastructure). These deficiencies are partly responsible for the water shortages and an intermittent water supply experienced by mostly poor neighbourhoods. This shows a policy gap between nonnetworked and intermittent water systems and large infrastructure, as shown in other cases (Allen et al., 2017). Despite this policy gap, politicians peddled the Zapotillo project as the only solution to bring about water security for Guadalajara, despite the supply augmentation most likely causing new water demand. Thus, this project would further continue the supply-demand cycle and thus increase the vulnerability of Guadalajara in the future.

In the case of León, although its urban water system characteristics are different than Guadalajara's, the effect of the supply augmentation Zapotillo project is similar. Our analysis shows that, due to its almost total water supply dependency on groundwater, León's water utility has improved its efficiency indicators better than Guadalajara's in terms of lower non-revenue water, higher percentage of networked households, and reclaimed water for agricultural purposes. However, its alarming groundwater situation, also affected by large-scale agricultural dynamics, is not likely going to change with a water transfer. Concerning the problem of groundwater overexploitation in the region, water managers need to consider radically different and equitable institutional arrangements between rural and urban users to curb its unsustainable water use, as suggested by Hoogesteger and Wester (2015) and Molle and Closas (2019) (see also Hoogendam, 2019, for a similar case in Cochabamba). 
Therefore, the similarity between the two cases lies in the way politicians overestimate the capacity of the large supply augmentation Zapotillo project to solve the current water problems and future challenges of these urban water systems. Moreover, these politicians also underestimate the potential of alternative solutions as well as the likely unintended negative consequences of such an infrastructure project, such as the supply-demand cycle (Kallis, 2010; Gohari et al., 2013) or the reservoir effect (Di Baldassarre et al., 2018).

The work of Leach et al. (2010) on development pathways argues for the need to unearth alternative, often marginalized pathways using different assessment tools and methods. Therefore, with a transdisciplinary approach, we analysed the emergence and dynamics of the competing alternative development pathway of the conflict. Our analysis on the decision space shows that the engineering mentality prevalent among water managers tended to dismiss any alternative pathway based on the perceived incapacity of the grassroots movement to show results or empirical evidence of the alternatives. Water managers also dismissed alternative solutions based on the lack of time and resources to investigate their merits, since the groundwater overexploitation and water shortages facing Guadalajara and León are so urgent that only the tried and tested, ready-made solution of the Zapotillo project is framed as feasible.

Transitioning to an alternative development pathway is usually faced with fierce opposition, since "[t]here is often assumed to be a singular path to progress, any questioning of which is taken to indicate an "“anti-innovation", "anti-technology" or "anti-development" stance" (Leach et al., 2010) and in the Zapotillo case personified by the opositodos. Critics often pitch a simplistic narrative of pitting the rights of the majority against the rights of the minority and ask the latter to sacrifice for the "common good" (Roy, 1999; Leach et al., 2010). This narrative frames the minority as the culprit for not accepting the project, which is left unquestioned. In fact, Scott (1998) and Agrawal (2005) explain that "high modernist" planning actively excludes political processes such as deliberation and negotiation precisely to avoid further questioning and preclude the emergence of alternatives.

Regarding the dynamics that determine the decision space of urban water systems, our experience from the participatory modelling process showed the importance of open science, not only to replicate results (Godinez Madrigal et al., 2020), but also to repurpose the design of a water resources model that was initially used to justify the Zapotillo project by expanding its system boundaries. By adding the Guadalajara and León water systems to the model, alternative water supply strategies could be tested, allowing participants to explore different strategies based on contrasting narratives.

The results of the participatory modelling workshop show that stakeholders critically reflect on the role of data, information, and scenarios that are often used to justify policies, decisions, and infrastructures ("because the situation can be analysed in a more integrated way, with more social criteria, not like the government's previous models", as said by the representative of Tómala). This critical perspective also allowed for a reflection on the purpose of water resources models as decision support systems. When an IMTA participant warned about the risk of giving a complex modelling tool to lay people, a representative of the grassroots movement acknowledged the assumptions and uncertainties of the model and foregrounded the key role of governance processes in relation to these unavoidable technical shortfalls of models. Participants of the grassroots movement were eager to participate in designing the model and deciding on the input information. This interest further contributed later to technical workshops with the federal government to develop alternatives to the Zapotillo project.

Therefore, we argue that in the socio-hydrological conceptualization of the supply-demand cycle and the reservoir effect, scientists need to pay special focus to the almost inevitable water conflicts inherent to endless supply augmentation projects and to the emergence of grassroots movements presenting alternative narratives. This can evolve into a development pathway crossroads that opens up the decision space as presented in Fig. 4. Based on our analysis of the cases of León and Guadalajara in relation to the Zapotillo project, water conflicts driven by grassroots movements have a role in disrupting the supply-demand cycle: first, by blocking and delaying the implementation of the large supply augmentation project, and second, by fostering a more conscientious public debate about the decision space of the urban water systems. The main narrative that framed the Zapotillo dam as a necessity and the only solution and ignored alternative solutions has changed. Water managers no longer ignore alternative solutions; at first, they criticized them, and now they take them seriously. Further research is needed to see if they will be implemented, but judging from the recent downscaling of the Zapotillo project, they may be forced to at least consider them. Without a large supply augmentation project, the cities will need to implement demand management (negative feedback for water demand in Fig. 4) and/or decentralized small-scale supply augmentation strategies (positive feedback for water supply in Fig. 4) that could thwart the supply-demand cycle.

\section{Conclusion}

This paper conceptualized and investigated the current development pathway crossroads of the cities of León and Guadalajara to understand the role of water conflicts and grassroots movements in interfering with the supply-demand cycle. It did so by analysing the urban water system trajectories that configured the present water scarcity and overexploitation problems in León and Guadalajara and exploring the sociopolitical dynamics of alternative future pathways proposed by actors in conflict. 


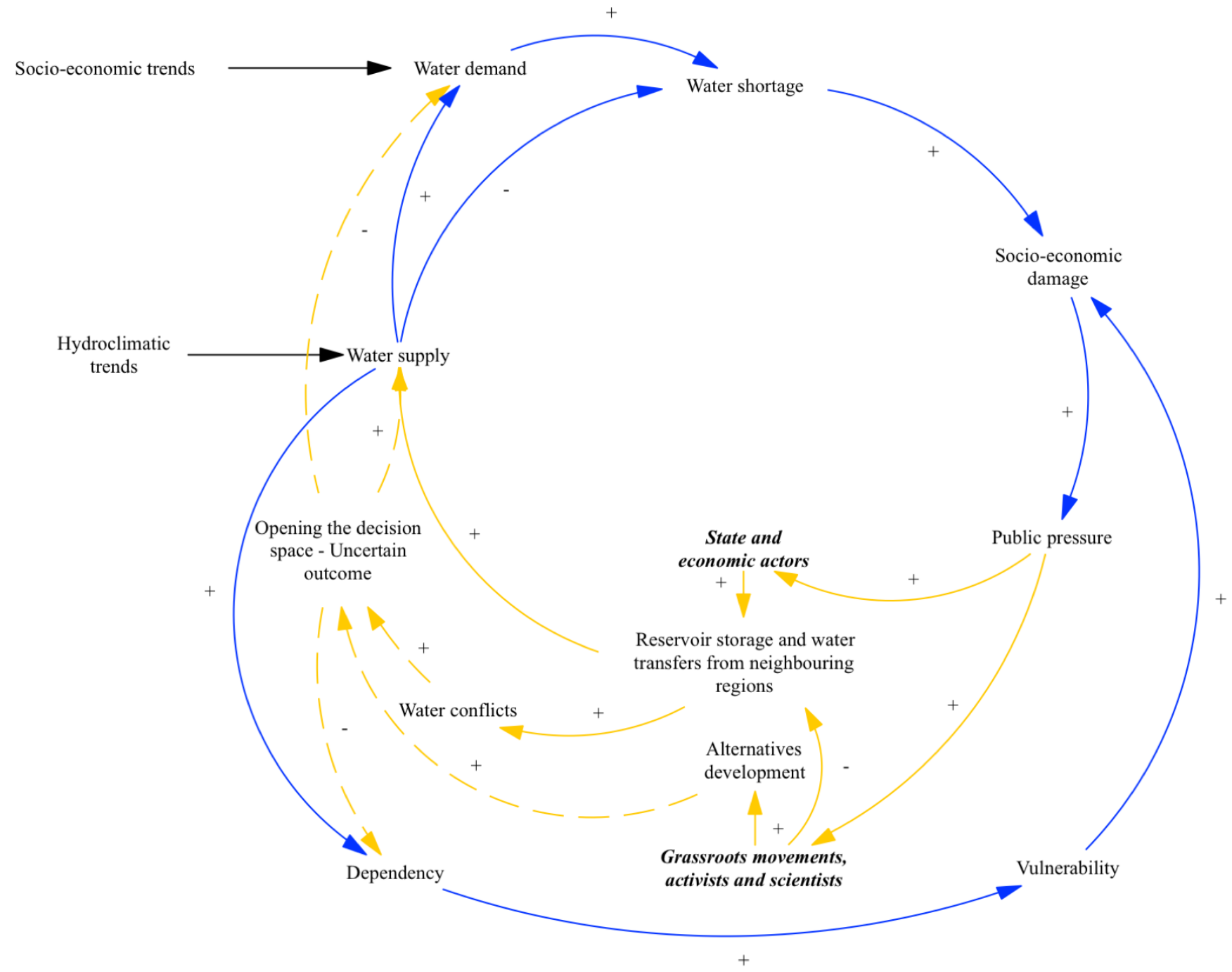

Figure 4. The water conflict disruption in the reservoir effect (the dashed lines indicate their hypothetical status, while the pink lines indicate new variables not yet considered by the original conceptualization by Di Baldassarre et al., 2018).

The dominant development pathway in León and Guadalajara has been characterized by a techno-managerial approach that went unchallenged for almost a century, what Leach et al. (2010) describe not as a pathway but a "motorway". However, in the last 3 decades this pathway has been heavily scrutinized and thoroughly criticized by a grassroots movement opposing this development pathway. This social opposition disrupted and caused large infrastructural projects to fail and put the Zapotillo project in an indefinite hiatus. This hiatus has lasted 15 years, and to date it remains unclear which development pathway León and Guadalajara will embark on.

With a transformative spirit infused by the work of Leach et al. (2010), Di Baldassarre et al. (2019), Zeitoun et al. (2020), and Rusca and Di Baldassarre (2019), we aimed at analysing the development pathways of urban water systems with a transdisciplinary political ecology and sociohydrology approach and explored the role of conflicts and grassroots movements in forcibly creating a development pathway crossroads. Our research showed that the methodological framework of socio-hydrology related to the reservoir effect (Di Baldassarre et al., 2018), combined with the critical political ecology approach of hydrosocial studies (Kallis, 2010; Molle and Wester, 2009; Savelli et al., 2021), can be used to problematize the sanctioned discourse of large supply augmentation infrastructure that is still dominant in other contexts. This exercise in conjunction with a participatory modelling workshop with key actors based on an empowering design (Stirling et al., 2007; Leach et al., 2010) can broaden what the issues at stake are in the urban water systems and open up the decision space beyond large supply augmentation infrastructure.

We broadened the issues by identifying that the main urban water problems are not only related to a gap of water supply and water demand over time, but also to an unchecked 
and even sponsored economic and population growth, uneven water access, ageing distribution infrastructure, and neglected rural-urban dynamics related to groundwater overexploitation. This is relevant because a large water supply augmentation project will not solve these issues. With our participatory modelling workshop, we contributed to opening up the decision space by modelling most of the alternative solutions brought up by the grassroots movement.

We arrived at three main conclusions. (1) The supplydemand cycle is fuelled by the perceived inevitability of urban and economic growth and an unwarranted faith that large-scale augmentation projects will solve complex current and future water problems like water shortages and groundwater overexploitation. (2) Water conflicts driven by grassroots movements have an important role in interfering with the supply-demand cycle by stalling the implementation of large infrastructure projects, creating a development pathway crossroads, and fostering public discussion on alternative pathways. (3) Participatory modelling is a promising tool to open the decision space by co-developing alternatives proposed by actors representing a competing pathway to have a more balanced deliberation and negotiation process, even in contexts of power asymmetry.

Code and data availability. The reader can access the SimVerde software as well as the data produced in the analysis of the different infrastructure configurations of SimVerde at https://github. com/jongmadrigal/SimVerde (last access: 8 February 2022) and https://doi.org/10.5281/zenodo.6010967 (Godinez Madrigal et al., 2018b).

Supplement. The supplement related to this article is available online at: https://doi.org/10.5194/hess-26-885-2022-supplement.

Author contributions. JGM, NVC, and PvdZ conceptualized the paper and the methodology. JGM and PCG curated the data. JGM conducted the formal analysis. JGM, JH, PCG, and NVC conducted the investigation. JGM and PCG contributed to the software. NVC and PvdZ supervised the project. JGM wrote the original draft, while NVC, JH, and PvdZ reviewed and edited the paper.

Competing interests. At least one of the (co-)authors is a member of the editorial board of Hydrology and Earth System Sciences. The peer-review process was guided by an independent editor, and the authors also have no other competing interests to declare.

Disclaimer. Publisher's note: Copernicus Publications remains neutral with regard to jurisdictional claims in published maps and institutional affiliations.
Special issue statement. This article is part of the special issue "Contributions of transdisciplinary approaches to hydrology and water resources management". It is not associated with a conference.

Acknowledgements. We would like to thank the two reviewers and the editor, for improving the paper with their valuable comments and suggestions. Additionally, we also want to thank the contribution of Joanne Craven in co-developing SimVerde, and to Lucía García, for her contribution to co-organizing the participatory modelling workshop.

Financial support. This research has been supported by the Consejo Nacional de Ciencia y Tecnología (grant no. 409777).

Review statement. This paper was edited by Tobias Krueger and reviewed by Elisa Savelli and one anonymous referee.

\section{References}

Agrawal, A.: Environmentality: Technologies of Government and the Making of Subjects, Duke University Press, Durham, https://doi.org/10.1515/9780822386421, 2005.

Ahlers, R., Zwarteveen, M., and Bakker, K.: Large dam development: from trojan horse to pandora's box, in: The Oxford Handbook of Megaproject Management, edited by: Flyvbjerg, B., Oxford University Press, https://doi.org/10.1093/oxfordhb/9780198732242.013.27, 2017.

Allan, T.: IWRM/IWRAM: a new sanctioned discourse?, School of Oriental and African Studies, Occasional, 1-27, 2003.

Allen, A., Hofmann, P., Mukherjee, J., and Walnycki, A.: Water trajectories through non-networked infrastructure: insights from peri-urban Dar es Salaam, Cochabamba and Kolkata, Urban Research and Practice, 10, 22-42, 2017.

Aristegui Noticias: En Guanajuato, IP y gobierno rechazan búsqueda de alternativas a la presa El Zapotillo, https://aristeguinoticias.com/1411/mexico/en-guanajuato-ipy-gobierno-rechazan-busqueda-de-alternativas-a-la-presa-elzapotillo/ (last access: November 2019), 14 November 2019.

Bakker, K.: Archipelagos and Networks: Urbanization and Water Privatization in the South, Geogr. J., 169, 328-341, https://doi.org/10.1111/j.0016-7398.2003.00097.x, 2003.

Basco-Carrera, L., van Beek, E., Jonoski, A., Benítez-Ávila, C., and Guntoro, F. P.: Collaborative modelling for informed decision making and inclusive water development, Water Resour. Manag., 31, 2611-2625, 2017.

Basco-Carrera, L., Meijers, E., Sarısoy, H. D., Şanli, N. O., Coşkun, S., Oliemans, W., Van Beek, E., Karaaslan, Y., and Jonoski, A.: An adapted companion modelling approach for enhancing multistakeholder cooperation in complex river basins, Int. J. Sust. Dev. World, 25, 747-764, 2018.

Bloomberg: Water Futures to Start Trading Amid Growing Fears of Scarcity, https:// www.bloomberg.com/news/articles/2020-12-06/ 
water-futures-to-start-trading-amid-growing-fears-of-scarcity (last access: 6 January 2022), 6 December 2020.

Boehm Schoendube, B.: Agua, Tecnología y sociedad en la Cuenca Lerma-Chapala: Una historia regional global, Nueva antropología, 19, 99-130, 2005.

Boelens, R.: Cultural politics and the hydrosocial cycle: Water, power and identity in the Andean highlands, Geoforum, 57, 234247, 2014.

Boelens, R., Shah, E., and Bruins, B.: Contested knowledges: Large dams and mega-hydraulic development, Water, 11, 416, https://doi.org/10.3390/w11030416, 2019.

Budds, J.: Contested $\mathrm{H}_{2} \mathrm{O}$ : Science, policy and politics in water resources management in Chile, Geoforum, 40, 418-430, 2009.

Cabrales-Barajas, L., Chávez-Hernánez, A., and Zaragoza-Vargas, F.: El Río Verde: Agua para Guadalajara, Carta Economica Regional, año 5, num. 29, http://www.cartaeconomicaregional. cucea.udg.mx/index.php/CER/article/view/7388 (last access: 10 February 2022), 1993.

Caldera-Ortega, A. R.: Gobernanza y sustentabilidad: desarrollo institucional y procesos políticos en torno al agua subterránea en México: los casos del valle de León y del valle de Aguascalientes, PhD thesis, FLACSO, México, 353 pp., https: //repositorio.flacsoandes.edu.ec/handle/10469/1781 (last access: 10 February 2022), 2009.

Caldera-Ortega, A. R.: La gestión del agua urbana de León, Guanajuato: Un análisis político de las ideas que dan forma a las políticas públicas y sus resultados, in: La crisis multidimensional del agua en la ciudad de León, Guanajuato, edited by: Tagle-Zamora, Universidad de Guanajuato-Porrúa, León, México, ISBN 978607-401-874-5, 2014.

Caldera-Ortega, A. and Tagle Zamora, D.: Saneamiento del agua en León, Guanajuato: Revisión de los conflictos desde el enfoque de la gobernanza ambiental democrática, in: El conflicto del agua: Política, gestión, resistencia y demanda social, edited by: Torregrosa, M. L., FLACSO Mexico, https://doi.org/10.2307/j.ctt21kk1ct.9, 2017.

Caldera-Ortega, A., Tagle Zamora, D., and Mazabel, D. G.: Guanajuato: crónica del cambio en su gestión del agua, in: Agua en el Bajío Guanajuatense, edited by: Caldera Ortega, A. and Tagle Zamora, D., Universidad de Guanajuato, Guanajuato, México, ISBN 978-607-441-802-6, 2020.

Camisa, Z. C.: Efecto de la migración en el crecimiento y la estructura de la población de las ciudades de la América Latina, Centro Latinoamericano de Demografía, https://repositorio.cepal.org/ bitstream/handle/11362/7915/S7200578_es.pdf?sequence $=1$ (last access: 21 June 2021), 1972.

Castillo-Girón, V., Revelo Hurtado, C., and Villalobos Torres, D.: Asentamientos irregulares en la zona metropolitana de Guadalajara: ¿expansión urbana inducida o crecimiento incontrolable?, Carta Económica Regional, 34, 32-39, http://www.cartaeconomicaregional.cucea.udg.mx/index.php/ CER/article/view/7517 (last access: 5 February 2022), 1994.

Castree, N., Adams, W. M., Barry, J., Brockington, D., Büscher, B., Corbera, E., Demeritt, D., Duffy, R., Felt, U., Neves, K., and Newell, P.: Changing the intellectual climate, Nat. Clim. Change, 4, 763-768, 2014.

CEA Guanajuato and Conagua: Factibilidad económica: Construcción del proyecto de abastecimiento de agua potable El Zapotillo, para la ciudad de León, Gto, document obtained through transparency procedures on 28 February 2020, 2018.

CEA Jalisco and Gobierno del Estado de Jalisco: Factibilidad económica: Actualización de la evaluación socioeconómica del proyecto de construcción de la presa y sistema de bombeo Purgatorio - Arcediano, para abastecimiento de agua al área Metropolitana de Guadalajara, Jalisco, document obtained through transparency procedures on 28 February 2020, 2018.

Conagua: PMPMS para usuarios urbanos de agua potable y saneamiento, https://www.gob.mx/cms/uploads/attachment/file/ 99855/PMPMS_ZM_Guadalajara_Jal.pdf (last access: 28 February 2020), 2015.

Conagua: Sistema Nacional de Información del Agua, http://sina. conagua.gob.mx/sina/tema.php?tema=cuencas (last access: 19 March 2020), 2018.

Conagua: Presa Zapotillo, Jal. Propuesta Conceptual Para Transitar Avenida de Diseño sin Afectar a Pobladores, Mexico DF, https://www.gob.mx/conagua/prensa/presentala-conagua-propuesta-de-operacion-de-la-presa-el-zapotillo-enjalisco?idiom=es (last access: 5 February 2022), November 2021.

CONAPO: Proyecciones de la Población de los Municipios de México, 2015-2030, https://www.gob.mx/conapo/documentos/proyecciones-dela-poblacion-de-los-municipios-de-mexico-2015-2030 (last access: 28 February 2020), 2015.

Consejo Consultivo del Agua: Gestión del agua en las ciudades de México: Indicadores de Desempeño de los Sistemas de Agua Potable, Alcantarillado y Saneamiento, http://www.aguas.org. $\mathrm{mx} / \mathrm{sitio} /$ index.php/de-interes/publicaciones (last access: 6 January 2022), 2011.

Cortés, S. A., Lozano, G. A., and Pérez, J.: Study of Water Quality Through Hydro-Chemical Signature in León, Guanajuato, Mexico, in: Water Stress in Biological, Chemical, Pharmaceutical and Food Systems, edited by: Gutiérrez-López, G. F., AlamillaBeltrán, L., del Pilar Buera, M., Welti-Chanes, J., Parada-Arias, E., and Barbosa-Cánovas, G. V., Springer Science+Business Media, New York, 549-556, 2015.

Costa-i-Font, J., Rodriguez-Oreggia, E., and Lunapla, D.: Political competition and pork-barrel politics in the allocation of public investment in Mexico, Public choice, 116, 185-204, 2003.

Craven, J.: SimBasin, http://joannecraven.co.uk/projects/simbasin/ (last access: 6 January 2022), 2018.

Del Castillo, A.: SIAPA, obeso de políticos y con pocos técnicos, http://agustindelcastillo.blogspot.com/2011/07/ siapa-obeso-de-politicos-y-con-pocos.html (last access: 17 December 2020), 2011.

Del Castillo, A.: Agua en el AMG, 27 años de omisiones, Milenio, https://cronicadesociales.wordpress.com/2018/03/23/ agua-en-el-amg-27-anos-de-omisiones/ (last access: 15 December 2020), 22 March 2018.

Del Castillo, A.: La demagogia del agua, El Respetable, http: //elrespetable.com/2021/03/11/la-demagogia-del-agua/ (last access: 6 January 2022), 11 March 2021.

Delgado-Aguiñaga, J. A. and Begovich, O.: Water Leak Diagnosis in Pressurized Pipelines: A Real Case Study, in: Modeling and Monitoring of Pipelines and Networks, edited by: Verde, C. and Torres, L., Applied Condition Monitoring, Vol. 7, Springer, Cham, https://doi.org/10.1007/978-3-319-55944-5_12, 2017. 
Di Baldassarre, G., Wanders, N., AghaKouchak, A., Kuil, L., Rangecroft, S., Veldkamp, T. I., Garcia, M., van Oel, P. R., Breinl, K., and Van Loon, A. F.: Water shortages worsened by reservoir effects, Nature Sustainability, 1, 617-622, https://doi.org/10.1038/s41893-018-0159-0, 2018.

Di Baldassarre, G., Sivapalan, M., Rusca, M., Cudennec, C., Garcia, M., Kreibich, H., Konar, M., Mondino, E., Mård, J., Pande, S., Sanderson, M. R., Tian, F., Viglione, A., Wei, J., Wei, Y., Yu, D., Srinivasan, V., and Blöschl, G.: Sociohydrology: Scientific challenges in addressing the sustainable development goals, Water Resour. Res., 55, 6327-6355, 2019.

Duran Juárez, J. M. and Torres Rodríguez, A.: Crisis ambiental en el lago de Chapala y abastecimiento de agua para Guadalajara, Carta Económica Regional, Vol. 14, http://www.cartaeconomicaregional.cucea.udg.mx/index.php/ CER/article/view/6155 (last access: 5 February 2022), 2001.

EJOLT: Mapping environmental unjustice, http://www.ejolt.org/ maps/, last access: 18 November 2021.

Esri: Ocean Basemap, https://www.arcgis.com/home/item.html?id= 6348e67824504fc9a62976434bf0d8d5 (last access: 12 February 2020), 2019.

Flores-Berrones, R.: Acueducto Chapala-Guadalajara, Ingeniería Hidráulica en México, January-April, p. 12, http://www. revistatyca.org.mx/index.php/tyca/article/view/556/460 (last access: 5 February 2022), 1987.

Flores-Elizondo, R.: Building Urban Water Resilience: New Perspectives for the Guadalajara Drought-readiness Program, Journal of Management for Global Sustainability, 4, 1-27, https://doi.org/10.13185/JM2016.04105, 2016.

Flörke, M., Schneider, C., and McDonald, R. I.: Water competition between cities and agriculture driven by climate change and urban growth, Nature Sustainability, 1, 51-58, https://doi.org/10.1038/s41893-017-0006-8, 2018.

Flyvbjerg, B.: Survival of the unfittest: why the worst infrastructure gets built - and what we can do about it, Oxford Rev. Econ. Pol., 25, 344-367, 2009.

Flyvbjerg, B.: What You Should Know about Megaprojects and Why: An Overview, Proj. Manag. J., 45, 6-19, https://doi.org/10.1002/pmj.21409, 2014.

Flyvbjerg, B., Bruzelius, N., and Rothengatter, W.: Megaprojects and risk: An anatomy of ambition, Cambridge University Press, https://doi.org/10.1017/CBO9781107050891, 2003.

García-Garnica, A.: Inicio y auge de las zonas industriales en México; el caso de la industria automotriz en Guanajuato, in: Innovación, Redes de Colaboración y Sostenibilidad, edited by: Martinez, A. and Carrillo, J., UNAM-Unidad León, ISBN 978-607437-381-3, 2017.

García Garnica, A. and Martínez-Martínez, A.: Trends of automotive industry FDI in Guanajuato, Mexico, Análisis económico, 33, 99-122, 2018.

Gleason, J. A. and Casiano, C.: Challenges of Water Sensitive Cities in Mexico: The Case of the Metropolitan Area of Guadalajara, Water, 13, 601, https://doi.org/10.3390/w13050601, 2021.

Global Water Partnership: Water demand management: A Mediterranean experience, Technical Focus Paper, https://www.gwp.org/globalassets/global/toolbox/publications/ technical-focus-papers/01-water-demand-management-themediterranean-experience-2012-english.pdf (last access: 6 January 2022), 2012.
Godinez Madrigal, J., van der Zaag, P., and van Cauwenbergh, N.: A half-baked solution: drivers of water crises in Mexico, Proc. IAHS, 376, 57-62, https://doi.org/10.5194/piahs-376-57-2018, 2018a.

Godinez Madrigal, J., Claure, P., Craven, J., Van Cauwenbergh, N., and van der Zaag, P.: SimVerde: Participatory decision support system for the Verde River Basin in Mexico in the context of the Zapotillo conflict, Zenodo [data set, code], https://doi.org/10.5281/zenodo.6010967, 2018b.

Godinez-Madrigal, J., Van Cauwenbergh, N., and van der Zaag, P.: Production of water knowledge in the face of water crises: Revisiting the IWRM Success Story of the Lerma-Chapala Basin, Mexico, Geoforum, 103, 3-15, https://doi.org/10.1016/j.geoforum.2019.02.002, 2019.

Godinez-Madrigal, J., Van Cauwenbergh, N., and van der Zaag, P.: Unraveling intractable water conflicts: the entanglement of science and politics in decision-making on large hydraulic infrastructure, Hydrol. Earth Syst. Sci., 24, 4903-4921, https://doi.org/10.5194/hess-24-4903-2020, 2020.

Gohari, A., Eslamian, S., Mirchi, A., Abedi-Koupaei, J., Bavani, A. M., and Madani, K.: Water transfer as a solution to water shortage: a fix that can backfire, J. Hydrol., 491, 23-39, 2013.

Gómez-Jauregui-Abdo, J. P.: Sustainable development of domestic water supply in emerging megacities: the case of the city of Guadalajara, Mexico, https://opus4.kobv.de/opus4-btu/files/ 3607/Gomez_Jauregui_Abdo.pdf (last access: 5 February 2022), 2015.

González-Valencia, M.: Los acaparadores del agua, Análisis plural, 201-218, https://rei.iteso.mx/bitstream/handle/11117/6419/ S4-Losacaparadoresdelagua.pdf?sequence $=1 \&$ isAllowed $=y$ (last access: 6 January 2022), 2020.

Greene, J.: Bottled water in Mexico: The rise of a new access to water paradigm, WIREs Water, 5, e1286, https://doi.org/10.1002/wat2.1286, 2018.

Greene, J.: What happens when water is commodified? Case study Mexico: dominant movements and alternative discourses in the access to water landscape, Doctoral dissertation, University of Geneva, https://doi.org/10.13097/archive-ouverte/unige:154585, 2021.

Gupta, J. and van der Zaag, P.: Interbasin water transfers and integrated water resources management: Where engineering, science and politics interlock, Phys. Chem. Earth, 33, 28-40, 2008.

Hernández-González, J.: Efectos de la urbanización metropolitana en la gestión del agua en las comunidades periurbanas. El caso de la zona metropolitana de León, in: Agua en el Bajío Guanajuatense, edited by: Caldera Ortega, A. and Tagle Zamora, D., Universidad de Guanajuato, Guanajuato, México, ISBN 978-607441-802-6, 2020.

Herrera, V.: Water and politics: Clientelism and reform in urban Mexico, University of Michigan Press, https://doi.org/10.3998/mpub.9210462, 2017.

Hoogendam, P.: Hydrosocial territories in the context of diverse and changing ruralities: The case of Cochabamba's drinking water provision over time, Water Int., 44, 129-147, https://doi.org/10.1080/02508060.2019.1551711, 2019.

Hoogesteger, J.: The ostrich politics of groundwater development and neoliberal regulation in Mexico, Water Altern., 11, 552-571, 2018. 
Hoogesteger, J. and Wester, P.: Intensive groundwater use and (in) equity: Processes and governance challenges, Environ. Sci. Policy, 51, 117-124, 2015.

Hoogesteger, J. and Wester, P.: Regulating groundwater use: The challenges of policy implementation in Guanajuato, Central Mexico, Environ. Sci. Policy, 77, 107-113, 2017.

Hommes, L. and Boelens, R.: Urbanizing rural waters: Rural-urban water transfers and the reconfiguration of hydrosocial territories in Lima, Polit. Geogr., 57, 71-80, https://doi.org/10.1016/j.polgeo.2016.12.002, 2017.

Hommes, L., Boelens, R., and Maat, H.: Contested hydrosocial territories and disputed water governance: Struggles and competing claims over the Ilisu Dam development in southeastern Turkey, Geoforum, 71, 9-20, 2016.

Hommes, L., Boelens, B., Harris, L. M., and Veldwisch, G.: Ruralurban water struggles: urbanizing hydrosocial territories and evolving connections, discourses and identities, Water Int., 44, 81-94, https://doi.org/10.1080/02508060.2019.1583311, 2019.

INEGI: Censo General de la República Mexicana 1900, https:// www.inegi.org.mx/programas/ccpv/1900/ (last access: 28 February 2020), 1900.

INEGI: Tercer Censo de Población de los Estados Unidos Mexicanos 1910, https://www.inegi.org.mx/programas/ccpv/1910/ (last access: 28 February 2020), 1910.

INEGI: Censo General de Habitantes 1921, https://www.inegi.org. mx/programas/ccpv/1921/ (last access: 28 February 2020), 1921.

INEGI: Quinto Censo de Población 1930, https://www.inegi.org. mx/programas/ccpv/1930/ (last access: 28 February 2020), 1930.

INEGI: Sexto Censo de Población 1940, https://www.inegi.org.mx/ programas/ccpv/1940/ (last access: 28 February 2020), 1940.

INEGI: Séptimo Censo General de Población 1950, https://www. inegi.org.mx/programas/ccpv/1950/ (last access: 28 February 2020), 1950.

INEGI: VIII Censo General de Población 1960, https://www.inegi. org.mx/programas/ccpv/1960/ (last access: 28 February 2020), 1960.

INEGI: IX Censo General de Población 1970, https://www.inegi. org.mx/programas/ccpv/1970/ (last access: 28 February 2020), 1970.

INEGI: X Censo General de Población y Vivienda 1980, https:// www.inegi.org.mx/programas/ccpv/1980/ (last access: 28 February 2020), 1980.

INEGI: XI Censo General de Población y Vivienda 1990, https:// www.inegi.org.mx/programas/ccpv/1990/ (last access: 28 February 2020), 1990.

INEGI: Conteo de Población y Vivienda 1995, https://www.inegi. org.mx/programas/ccpv/1995/ (last access: 28 February 2020), 1995.

INEGI: XII Censo general de población y vivienda 2000, https:// www.inegi.org.mx/programas/ccpv/2000/ (last access: 28 February 2020), 2000.

INEGI: II Conteo de Población y Vivienda 2005, https://www.inegi. org.mx/programas/ccpv/2005/ (last access: 28 February 2020), 2005.

INEGI: Censo de población y vivienda 2010, https://www.inegi.org. mx/programas/ccpv/2010/ (last access: 28 February 2020), 2010.

INEGI: Encuesta intercensal 2015, https://www.inegi.org.mx/ programas/intercensal/2015/ (last access: 28 February 2020), 2015.
Jalomo Aguirre, F.: Gobernar el territorio entre descentralización y metropolización: el patronato y el SIAPA como formas de gestión (1952-2006) y escenarios prospectivos, Universidad de Guadalajara, Guadalajara, https://issuu.com/publicaciones_ cucsh/docs/francisco_jalomo1 (last access: 6 January 2022), 2011.

Kallis, G.: Coevolution in water resource development. The vicious cycle of water supply and demand in Athens, Greece, Ecol. Econ., 69, 796-809, https://doi.org/10.1016/j.ecolecon.2008.07.025, 2010.

Konijnenberg, V.: León's water system, MSc Thesis, Water Resources Management Group, Wageningen University, 2019.

Kuil, L., Carr, G., Viglione, A., Prskawetz, A., and Blöschl, G.: Conceptualizing socio-hydrological drought processes: The case of the Maya collapse, Water Resour. Res., 52, 6222-6242, 2016.

Lach, D., Rayner, S., and Ingram, H.: Taming the waters: strategies to domesticate the wicked problems of water resource management, Int. J. Water, 3, 1-17, 2005.

Larsen, T. A., Hoffmann, S., Lüthi, C., Truffer, B., and Maurer, M.: Emerging solutions to the water challenges of an urbanizing world, Science, 352, 928-933, 2016.

Lave, R., Wilson, M. W., Barron, E. S., Biermann, C., Carey, M. A., Duvall, C. S., Johnson, L., Lane, K. M., McClintock, N., Munroe, D., and Pain, R.: Intervention: Critical physical geography, Can. Geogr., 58, 1-10, 2014.

Leach, M., Scoones, I., and Stirling, A.: Dynamic Sustainabilities: Technology, Environment, Social Justice, Earthscan, London, ISBN 978-18-4971-093-0, 2010.

Li, B., Sivapalan, M., and Xu, X.: An urban sociohydrologic model for exploration of Beijing's water sustainability challenges and solution spaces, Water Resour. Res., 55, 5918-5940, 2019.

Linton, J. and Budds, J.: The hydrosocial cycle: Defining and mobilizing a relational-dialectical approach to water, Geoforum, 57, 170-180, 2014.

López-Ramírez, M. E.: Conflicto y agentes en el caso de La presa Arcediano: la gestión pública del agua en la zona metropolitana de Guadalajara, in: Gobernanza y gestion del agua en el Occidente de Mexico: La metrópoli de Guadalajara, edited by: Ochoa-García, H. and Bürkner, H. J., ITESO, Tlaquepaque, ISBN 978-607-7808-66-4, 2012.

López-Ramírez, M. E. and Ochoa-Garcia, H.: Geopolitica del agua en la zona metropolitana de Guadalajara: historia y situación actual del espacio vital, in: Gobernanza y gestion del agua en el Occidente de Mexico: La metrópoli de Guadalajara, edited by: Ochoa-García, H. and Bürkner, H. J., ITESO, Tlaquepaque, ISBN 978-607-7808-66-4, 2012.

Lozano, G.: La crisis del agua en León: Claves para su comprensión, in: La crisis multidimensional del agua en la ciudad de León, Guanajuato, edited by: Tagle-Zamora, D., Universidad de Guanajuato-Porrúa, León, México, ISBN 978-607-401-8745, 2014.

Maxmen, A.: As Cape Town water crisis deepens, scientists prepare for "Day Zero", Nature, 554, 13-14, https://doi.org/10.1038/d41586-018-01134-x, 2018.

McCulligh, C. and Tetreault, D.: Water Management in Mexico. From Concrete-Heavy Persistence to Community-Based Resistance, Water Altern., 10, 341-369, 2017.

McCulligh, C., Arellano-García, L., and Casas-Beltrán, D.: Unsafe waters: the hydrosocial cycle of drinking wa- 
ter in Western Mexico, Local Environment, 25, 576-596, https://doi.org/10.1080/13549839.2020.1805598, 2020.

Mekonnen, M. M. and Hoekstra, A. Y.: Four billion people facing severe water scarcity, Sci. Adv., 2, e1500323, https://doi.org/10.1126/sciadv.1500323, 2016.

Melsen, L. A., Vos, J., and Boelens, R.: What is the role of the model in socio-hydrology? Discussion of "Prediction in a sociohydrological world", Hydrolog. Sci. J., 63, 1435-1443, 2018.

Molle, F.: Why enough is never enough: The societal determinants of river basin closure, Int. J. Water Resour. D., 24, 217-226, 2008.

Molle, F. and Closas, A.: Comanagement of groundwater: A review, WIREs Water, 7, e1394, https://doi.org/10.1002/wat2.1394, 2019.

Molle, F. and Wester, P. (Eds.): River basin trajectories: societies, environments and development, Vol. 8, IWMI, ISBN 978-184593-538-2, 2009.

Molle, F., Mollinga, P. P., and Wester, P.: Hydraulic bureaucracies and the hydraulic mission: Flows of water, flows of power, Water Altern., 2, 328-349, 2009.

Ochoa-García, H. and Rist, S.: Water justice and integrated water resources management: constitutionality processes favoring sustainable water governance in Mexico, Hum. Ecol., 46, 51-64, 2018.

Ochoa-García, H., Arrojo-Agudo, P., Godínez-Madrigal, J., LópezVillegas, P., López-Aguayo, A., and Quiroz-Hernández, M. L.: Agua para el desarrollo regional en los Altos de Jalisco, Gestión del agua e impacto social del proyecto El Zapotillo, ITESO, http://hdl.handle.net/11117/2641 (last access: 6 February 2022), 2014.

Pastrana, D., Ramirez, J., and Ramos C.: Guanajuato. El costo del agua que no llega al nuevo Bajío industrial, El Universal, https://www.eluniversal. com.mx/articulo/periodismo-de-investigacion/2017/08/

11/guanajuato-el-costo-del-agua-que-no-llega-al-nuevo and https://ladobe.com.mx/2017/08/ empresas-espanolas-costo-del-nuevo-bajio-industrial/ (last access: 5 January 2022), 11 August 2017.

Pérez-Peña, O. and Torres-González, G.: La insaciable sed de agua de la zona metropolitana de Guadalajara, Renglones, núm. 49, http://hdl.handle.net/11117/432 (last access: 6 February 2022), 2001.

Pérez-Peña, O., Torres-González, G., and Romo-Reyes, M.: Agua y mas agua para la zona conurbada de Guadalajara: La gestión no sustentable del recurso hídrico, in: La gestión del recurso hídrico: Realidades y perspectivas, edited by: Soares, D., Vargas, S., Pérez-Peña, O., and Ramírez, A. I., 154-174, Instituto Mexicano de Tecnología del Agua, ISBN 978-607-7563-04-4, 2009.

Pfannenstein, B., Anacleto Herrera, E. E., and Sevilla Villalobos, S.: La ciudad cerrada y su diversificación como reto del Área Metropolitana de Guadalajara, México, Rev. Geogr. Norte Gd., 68, 163-184, 2017.

Platt, R. H.: The 2020 Water Supply Study for Metropolitan Boston, J. Am. Plann. Assoc., 61, 185-199, 1995.

Purvis, L. and Dinar, A.: Are intra-and inter-basin water transfers a sustainable policy intervention for addressing water scarcity?, Water Security, 9, 100058, https://doi.org/10.1016/j.wasec.2019.100058, 2020.
Reis, N.: Finance capital and the water crisis: Insights from Mexico, Globalizations, 14, 976-990, 2017.

Rinaudo, J. D. and Barraqué, B.: Inter-basin transfers as a supply option: the end of an era? in: Understanding and Managing Urban Water in Transition, edited by: Grafton, Q., Daniell, K. A., Nauges, C., Rinaudo, J.-D., and Chan, N. W. W., Springer, Berlin, 175-200, https://doi.org/10.1007/978-94-017-9801-3_8, 2015.

Rodríguez, M. D.: Sobrexplotación de mantos acuíferos genera conflictos a habitantes de León, La Jornada, https://www. jornada.com.mx/2004/05/20/047n1 soc.php?printver=1\&fly= (last access: 7 January 2021), 19 May 2004.

Rodríguez, M. D.: Sin agua, León, Guanajuato; sólo tiene reservas para 10 años, La Jornada, https://www.jornada.com.mx/2008/02/ 02/index.php?section $=$ estados \&article $=027 \mathrm{n} 1$ est (last access: 15 December 2020), 2 February 2008.

Rodríguez-Labajos, B. and Martínez-Alier, J.: Political ecology of water conflicts, WIREs Water, 2, 537-558, 2015.

Roy, A.: The greater common good, Frontline, https://frontline. thehindu.com/other/article30257333.ece (last access: 5 February 2022), 22 May 1999.

Rubino, F., Corona, Y., Jiménez Pérez, J. G., and Smith, C.: Bacterial contamination of drinking water in Guadalajara, Mexico, Int. J. Env. Res. Pub. He., 16, 67, https://doi.org/10.3390/ijerph16010067, 2019.

Rusca, M. and Di Baldassarre, G.: Interdisciplinary critical geographies of water: Capturing the mutual shaping of society and hydrological flows, Water, 11, 1973, https://doi.org/10.3390/w11101973, 2019.

SAPAL: El agua en León, Un encuentro con el futuro, https:// www.sapal.gob.mx/media/files/1505769928-elagua.pdf (last access: 5 February 2022), 2009.

SAPAL: Trayectoria y futuro, https://www.sapal.gob.mx/media/ files/1553888365-SAPAL_Trayectoria_y_Futuro_2012.pdf (last access: 5 February 2022), 2012.

SAPAL: El agua subterránea en Guanajuato, Profundidad del nivel estático 2015, https://agua.guanajuato.gob.mx (last access: 13 January 2021), 2015.

SAPAL: Agua Siempre y Para Todos: Informe de Resultados 2013-2016, León, https://www.sapal.gob.mx/media/files/ 1456268400-InformeConsejo2013-2016.pdf (last access: 5 February 2022), 2016.

SAPAL: Data on León's water supply since 1988, data obtained through transparency procedures on 2 March 2020, 2020.

Savelli, E., Rusca, M., Cloke, H., and Di Baldassarre, G.: Don't blame the rain: Social power and the 20152017 drought in Cape Town, J. Hydrol., 594, 125953, https://doi.org/10.1016/j.jhydrol.2020.125953, 2021.

Schlosser, C. A., Strzepek, K., Gao, X., Fant, C., Blanc, É., Paltsev, S., Jacoby, H., Reilly, J., and Gueneau, A.: The future of global water stress: an integrated assessment, Water Resour. Res., 2, 341-361, 2014.

Schmidt, J. J.: Historicising the hydrosocial cycle, Water Altern., 7 , 220-234, 2014.

Scott, J.: Seeing Like a State. How Certain Schemes to Improve the Human Condition Have Failed, Yale University Press, New Haven, ISBN 0300-078153, 1998.

SIAPA: Plan Institucional 2014-2018 del SIAPA, https: //www.siapa.gob.mx/sites/default/files/doctrans/plan_ 
institucional_siapa_2014-2018.pdf (last access: 21 December 2020), 2014a.

SIAPA: Cronología de las fuentes de abastecimiento para Guadalajara, Proceedings from the congress "Abastecimiento de agua a las metrópolis del país”, 17 July 2014, Guadalajara, Mexico, 2014b.

SIAPA: Abastecimiento de agua para Guadalajara: El río del tiempo, available upon request to SIAPA, 2016.

SIAPA: Data on Guadalajara's water supply since 1988, data obtained through transparency procedures on 15 January 2020, 2020.

Sivapalan, M. and Blöschl, G.: Time scale interactions and the coevolution of humans and water, Water Resour. Res., 51, 6988$7022,2015$.

Srinivasan, V., Sanderson, M., Garcia, M., Konar, M., Blöschl, G., and Sivapalan, M.: Moving socio-hydrologic modelling forward: unpacking hidden assumptions, values and model structure by engaging with stakeholders: reply to "What is the role of the model in socio-hydrology?”, Hydrolog. Sci. J., 63, 1444-1446, 2018.

Stirling, A., Leach, M., Mehta, L., Scoones, I., Smith, A., Stagl, S., and Thompson, J.: Empowering Designs: towards more progressive social appraisal of sustainability, STEPS Centre, Brighton, https://opendocs.ids.ac.uk/opendocs/handle/ 20.500.12413/2473 (last access: 6 February 2022), 2007.

Swyngedouw, E.: Power, nature, and the city. The conquest of water and the political ecology of urbanization in Guayaquil, Ecuador: 1880-1990, Environ. Plann. A, 29, 311-332, 1997.

Swyngedouw, E.: Social power and the urbanization of water: flows of power, Vol. 226, Oxford University Press, Oxford, 2004.

Swyngedouw, E.: The political economy and political ecology of the hydro-social cycle, Journal of Contemporary Water Research and Education, 142, 56-60, 2009.

Tagle-Zamora, D. and Caldera-Ortega, A. R.: Corporatización de tipo neoliberal en la gestión del agua en México. Lecciones de León. Guanajuato, Tecnol. Cienc. Agua, 12, 207-271, 2021.

Torres Rodríguez, A.: Infraestructura hidráulica en Guadalajara para el abastecimiento de agua potable: el caso de sustentabilidad en las galerías filtrantes de Guadalajara, SciELO, 34, 317357, 2013.

UASLP (Universidad Autónoma de San Luis Potosí) and CEA Jalisco: Propuesta metodológica para la implantación de una batería de indicadores de salud que favorezcan el establecimiento de programas de diagnóstico, intervención y vigilancia epidemiológica en las poblaciones ubicadas en la zona de influencia de la Presa Arcediano en el Estado de Jalisco, https://transparencia.info.jalisco.gob.mx/sites/default/files/u531/ INFORMEFINALARCEDIANO_CEA_UEAS_JALISCO_ 2011_1-copia_opt.pdf (last access: 22 June 2021), 2010.
UNESCO, UN-Water: United Nations World Water Development Report 2020: Water and Climate Change, Paris, UNESCO, ISBN 978-92-3-100371-4, 2020.

Van Cauwenbergh, N., Ciuró, A. B., and Ahlers, R.: Participatory processes and support tools for planning in complex dynamic environments, Ecol. Soc., 23, 2, https://doi.org/10.5751/ES-09987230202, 2018.

Villalobos-Aragón, A., Ellis, A. S., Armienta, M. A., MortonBermea, O., and Johnson, T. M.: Geochemistry and Cr stable isotopes of Cr-contaminated groundwater in León valley, Guanajuato, México, Appl. Geochem., 27, 1783-1794, https://doi.org/10.1016/j.apgeochem.2012.02.013, 2012.

Vörösmarty, C. J., McIntyre, P. B., Gessner, M. O., Dudgeon, D., Prusevich, A., Green, P., Glidden, S., Bunn, S. E., Sullivan, C. A., Liermann, C. R., and Davies, P. M.: Global threats to human water security and river biodiversity, Nature, 467, 555-561, https://doi.org/10.1038/nature09549, 2010.

Wesselink, A., Kooy, M., and Warner, J.: Socio-hydrology and hydrosocial analysis: toward dialogues across disciplines, WIREs Water, 4, e1196, https://doi.org/10.1002/wat2.1196, 2017.

Wester, P., Scott, C. A., and Burton, M.: River basin closure and institutional change in Mexico's Lerma-Chapala Basin, in: Irrigation and River Basin Management. Options for Governance and Institutions, chap. 8, edited by: Svendsen, M., CABI Publishing, 125-144, https://doi.org/10.1079/9780851996721.0125, 2005.

WWAP (UNESCO World Water Assessment Programme): The United Nations World Water Development Report 2019: Leaving No One Behind, Paris, UNESCO, ISBN 978-92-3-100309-7, 2019.

Zeitoun, M., Mirumachi, N., Warner, J., Kirkegaard, M., and Cascão, A.: Analysis for water conflict transformation, Water Int., 45, 365-384, https://doi.org/10.1080/02508060.2019.1607479, 2020.

Zwarteveen, M., Kemerink-Seyoum, J.S., Kooy, M., Evers, J., Guerrero, T.A., Batubara, B., Biza, A., Boakye-Ansah, A., Faber, S., Cabrera Flamini, A., Cuadrado-Quesada, G., Fantini, E., Gupta, J., Hasan, S., ter Horst, R., Jamali, H., Jaspers, F., Obani, P., Schwartz, K., Shubber, Z., Smit, H., Torio, P., Tutusaus, M., and Wesselink, A.: Engaging with the politics of water governance, WIREs Water, 4, e1245, https://doi.org/10.1002/wat2.1245, 2017. 